\author{
Elżbieta Ziemianin-Profic \\ Zespoł Szkół Zawodowych i Ogólnokształcących, Sułkowice
}

\title{
Refleksje na temat udziału i koordynacji akcji „Dzień Przedsiębiorczości”
}

\begin{abstract}
„Dzień Przedsiębiorczości” to akcja, która dawała szansę na lepsze przygotowanie młodzieży do wejścia na rynek pracy i karierę zawodową. Dawała również szansę na wykorzystanie w praktyce wiedzy zdobytej w szkole, wykonywanie zadań na wymarzonym stanowisku pracy jak również weryfikację wyboru kierunku dalszego kształcenia i planowania kariery zawodowej. Umożliwiała również udział w konkursach na reportaż i fotoreportaż z „Dnia Przedsiębiorczości”.

Organizatorem tego dnia była Kancelaria Prezydenta RP, Fundacja Młodzieżowej Przedsiębiorczości, oraz Polska Konfederacja Pracodawców. W programie mogły brać udział wszystkie szkoły z całej Polski (klasy I i II liceów ogólnokształcących). Akcja odbyła się 27 kwietnia $2004 \mathrm{r}$.
\end{abstract}

\section{D E A TEGO DNIA BYEO:}

- Włączenie środowisk przedsiębiorców w edukację młodzieży.

- Stworzenie nowatorskiej płaszczyzny przekazywania młodym ludziom wiedzy o funkcjonowaniu na rynku pracy.

- Zbudowanie mostów między szkołą a miejscem pracy.

CO „DZIEŃ PRZEDSIĘBIORCZOŚCI” DAE S Z K O L E :

- Szkoła otrzymała narzędzie do motywowania uczniów do większego zainteresowania nauką.

- Zyskała sojuszników w dobrym przygotowaniu uczniów do wejścia na rynek pracy.

CO „DZIEŃ PRZEDSIĘBIORCZOŚCI” DAE U C Z N I O M :

- Umożliwił bezpośrednie poznanie wymagań stawianych pracownikom na różnych stanowiskach $w$ danej branży.

- Unaocznił związek między wykształceniem i karierą zawodową, motywując uczniów do zainteresowania się nauką i samokształceniem.

- Sprzyjał podejmowaniu trafnych decyzji w planowaniu dalszej drogi edukacyjnej i zawodowej.

- Pozwolił porównać wyobrażenia o danym zawodzie, stanowisku pracy z rzeczywistością i je zweryfikować.

- Pomógł przygotować się młodzieży do lepszego poszukiwania pracy w krajach Unii Europejskiej.

CO „DZIEŃ PRZEDSIĘBIORCZOŚCI” DAE MI N A U C Z Y C I E L O W I-KOORDYNATOROWI AKCJI:

- Umożliwił mi doskonalenie moich umiejętności niezbędnych przy realizacji interdyscyplinarnych projektów badawczych. 
- Umożliwił mi poznanie i analizę różnorodnych wypadków związanych z wyborem i weryfikacją dalszej drogi edukacyjnej i zawodowej uczniów w ramach działań wychowawczych.

W Naszej szkole tj. Zespole Szkół Zawodowych i Ogólnokształcących w Sułkowicach chęć udziału w akcji zgłosiły dwie klasy liceów ogólnokształcących (22 osoby z klasy I i 23 osoby z klasy II). W szkole zostałam powołana na szkolnego koordynatora. Moim zadaniem było:

- Zapoznanie Dyrekcji i Rady Pedagogicznej z celami i warunkami włączenia się szkoły w „Dzień Przedsiębiorczości”;

- Przygotowanie uczniów wspólnie z wychowawcą klasy do udziału w akcji;

- Zapoznanie rodziców z założeniami akcji;

- Zgłoszenie na stronie www.junior.org.pl firm i konsultantów, którzy złożyli „kartę zgłoszenia konsultanta-opiekuna ucznia „w szkole;

- Wyszukiwanie przedsiębiorstw i instytucji na stronach internetowych, które zgłosiły swój udział i wskazały proponowane miejsca pracy dla zainteresowanych uczniów (ze względu na brak zgłoszonych firm drogą internetową - szkolny koordynator akcji musiał sam szukać firm chętnych przyjąć uczniów w tym dniu);

- Dobór stanowisk pracy w poszczególnych firmach dla uczniów zgodnie z deklarowanymi zainteresowaniami;

\section{REALIZACJA „DNIA PRZEDSIĘBIORCZOŚCI” - 27 KWIETNIA 2004 R.}

1) Omówienie przebiegu „Dnia” $\mathrm{z}$ uczestnikami. Pomoc uczniom w zanalizowaniu doświadczeń wyniesionych z udziału w tym „Dniu” dla budowania ich ścieżki edukacyjnej;

2) Sporządzenie sprawozdania i przedstawienie go Radzie Pedagogicznej, rodzicom i wysłanie fundacji;

3) Opracowanie podziękowań dla konsultantów wspólnie z młodzieżą i wysłanie ich do firm. ;

Pomimo wielu formalności, które musiałam spełnić jako szkolny koordynator (min. formularze zgód rodziców, zgód zakładów pracy), z naszej szkoły w akcji brało udział 45 uczniów. Osoby te w dniu 27 kwietnia 2004 r. obserwowały pracę w 38 zakładach pracy, które to wyraziły chęć na przyjęcie uczniów- obserwatorów. Zakłady te prowadziły działalność w najbliższej okolicy, w Sułkowicach, Myślenicach i w Krakowie. Branże, w których prowadziły działalność te firmy były też bardzo zróżnicowane (zgodnie z zainteresowaniami uczniów) - począwszy od handlu, usług, administracji, edukacji a na sądownictwie skończywszy. Zakończeniem tej akcji była „GALA PRZEDSIĘBIORCZOŚĆI”, na którą zaproszone były najbardziej aktywne szkoły i zakłady pracy.

Własne przemyślenia na temat zalet i problemów związanych z organizacją „Dnia Przedsiębiorczości” zawiera poniższe zestawienie:

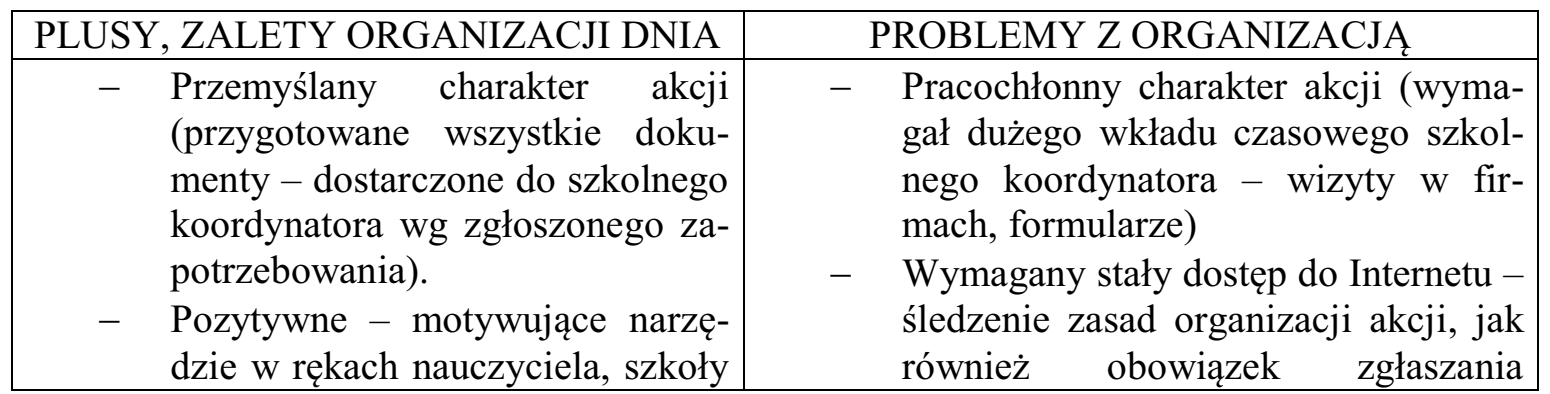




\begin{tabular}{|c|c|c|c|}
\hline- & $\begin{array}{l}\text { skierowane na ucznia. } \\
\text { Poprzedzenie „Dnia Przedsiębior- } \\
\text { czości” spotkaniami przygotowu- } \\
\text { jącymi uczestników do udziału w } \\
\text { akcji - uświadomienie zasad, ce- } \\
\text { lów akcji. } \\
\text { Podsumowanie akcji - wyciągnię- } \\
\text { cie wniosków przez szkolnego } \\
\text { koordynatora, pomoc w dokona- } \\
\text { niu analizy i weryfikacji zebra- } \\
\text { nych informacji o miejscach pra- } \\
\text { cy, weryfikacja ich z rzeczywisto- } \\
\text { ścią (wiele osób utwierdziło się w } \\
\text { swoim wyborze zawodu, lecz były } \\
\text { i osoby w których przypadku we- } \\
\text { ryfikacja ta była negatywna - de- } \\
\text { cyzja o zmianie dalszej drogi edu- } \\
\text { kacyjnej jak i zawodowej). } \\
\text { Wspólne z młodzieżą opracowa- } \\
\text { nie podziękowań dla konsultantów } \\
\text { i wysłanie ich, bądź osobiste do- } \\
\text { starczenie do firmy. }\end{array}$ & - & $\begin{array}{l}\text { uczniów jak i firm na specjalnej stro- } \\
\text { nie internetowej do udziału w akcji. } \\
\text { Nie wszyscy uczniowie mieli możli- } \\
\text { wość uczestnictwa w obserwacji } \\
\text { „wymarzonego" stanowiska pracy - } \\
\text { problem ze zgodami firm; } \\
\text { Część uczniów nie wiedziała, jaką } \\
\text { ścieżkę edukacyjną chce wybrać, w } \\
\text { związku z tym miała problem z wybo- } \\
\text { rem zawodu do obserwacji (problem } \\
\text { klas 1); } \\
\text { Niektóre firmy (szczególnie placówki } \\
\text { budżetowe) wymagały sporządzania } \\
\text { dodatkowych podań dotyczących zgo- } \\
\text { dy na udział w akcji; } \\
\text { Mała możliwość znalezienia zakładów } \\
\text { w najbliższej okolicy chętnych przy- } \\
\text { jąć uczniów na obserwację np. pracy } \\
\text { sędziów, adwokatów (ze względu na } \\
\text { tajność niektórych informacji czy też } \\
\text { nieodpowiedni wiek uczniów). }\end{array}$ \\
\hline
\end{tabular}

Pomimo dużej ilości problemów z organizacją - bardzo gorąco zachęcam do włączenia się w tę akcję, która dzięki swojej niespotykanej, niekonwencjonalnej formie wnosi bardzo dużo w życie młodych ludzi, „otwiera” im oczy na rzeczywistość.

Aby lepiej ukazać „opłacalność” udziału w akcji i zachęcić inne szkoły do udziału w tym dniu przedstawię opinie młodzieży na temat tej akcji, uzyskane dzięki wypełnieniu przez nich anonimowej ankiety. Pytania w ankiecie dotyczyły m.in. kwestii:

- czy organizacja w przyszłości takiej akcji ma sens?

- co uczestnikom dał udział w tej akcji?

- czy ankietowani zachęciliby kolegów, koleżanki do udziału w tej akcji?

- czy przedsięwzięcie, jakim był „Dzień Przedsiębiorczości”, spełniło oczekiwania uczestników?

- czy zamierzenia typu: lepsza orientacja na rynku pracy czy też konfrontacja swoich wyobrażeń o wymarzonym zawodzie z rzeczywistością zostały osiągnięte?

Akcję „Dzień Przedsiębiorczości” młodzież oceniła bardzo pozytywnie, nie był to dla nich „dzień bez szkoły” - lecz dzień zdobywania nowych doświadczeń i umiejętności. Był to zarówno dla uczniów, jak i firm dobry sprawdzian, dający możliwość konfrontacji oczekiwań uczniów wobec przyszłych ich przełożonych z rzeczywistością, a pracodawcom dał szansę na poznanie postaw przyszłych potencjalnych pracowników. Zakłady pracy miały możliwość włączenia się w edukację młodzieży, stworzenia mostów między szkołą a konkretnym miejscem pracy. Firmy te miały również możliwość przekazania wiedzy o funkcjonowaniu w obecnych warunkach za pomocą nowatorskich metod, dzięki czemu wiedza ta została przekazana uczniom w sposób jasny i rzetelny. Każdy z uczestników akcji zachęciłby znajomych do udziału w tej akcji, i z zapałem deklaruje chęć uczestnictwa w kolejnej edycji. Wielu uczniów zaczęła dopiero teraz zwracać uwagę na to, co chce w przyszłości robić jaki zawód wykonywać, a przez to zaczęła zastanawiać się nad przedmiotami maturalnymi nad ich wyborem. 
Z przebiegu i organizacji tej akcji młodzież była zadowolona. Mieli oni możliwość zobaczenia jak ich wymarzony zawód - praca wygląda w rzeczywistości, na jakich realiach jest oparta.

Akcje tego typu moim zdaniem powinny częściej być organizowane, gdyż wiedza podczas nich zdobyta lepiej, szybciej dociera do ucznia niż niejedna książka i wykład. 